\title{
The Effect Analysis of Liquidity, Solvency on Profitability and Its Impact to the Company Value at PT KS, Tbk
}

\author{
Masno Marjohan \\ Universitas Pamulang, Indonesia \\ masnomarjohan@yahoo.co.id
}

\begin{abstract}
The purpose of this study is to analyze the company's ability to pay short-term debt and long-term debt, and this study is also to determine the effect on profitability and its impact on the firm value of the manufacturing industry listed on the Indonesia Stock Exchange (Tbk). The data is obtained from the company's annual reports from 2009 to 2018. The research method used by the author is quantitative descriptive method, by analyzing financial reports with quantitative data obtained from the company's official website and the Indonesia Stock Exchange. Management of statistical data usingEviews. The result of the research is to get the influence between variable $X 1$, variable $Y$ and $X 2$ with variable $Y$, and simultaneously and variable $Y$ to variable $Z$ (Company value) by using multiple linear analysis obtained a regression equation. Calculation of the coefficient of determination or $R$ Square, This shows that Liquidity (Current Ratio) and Solvency (Debt to Asset Ratio) have an influence on Profotability (Return on Assets) while the rest is influenced by other variables. Partially the liquidity variable (Current Ratio) has a significant influence on Profitability (Return on Assets), while partially there is an insignificant effect of Debt to Asset Ratio on Profitability (Return on Assets).
\end{abstract}

\section{Keywords}

Liquidity, solvency, profitability, firmvalue

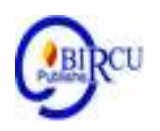

\section{Introduction}

To be able to attract the attention of investors so that they want to invest in the company, the company managers or company leaders must be able to increase the overall profit or profit of the company by using the resources owned by the company itself.

To be able to help investors, companies and other interested people know the financial condition, financial reports are needed. The financial reporting tool that is often used is financial ratio analysis. From these financial ratios, there are liquidity ratios and profitability ratios that are the main concern for companies, especially corporate financial managers, because from the results of the liquidity ratios, it can be seen that the company's ability to meet short-term obligations and profitability ratios can provide information about the company's capabilities. in generating profit or profit. In addition to the liquidity ratio and profitability ratio, there is also a solvency ratio or leverage ratio.

From the results of the pre-survey the author will take data from the IDX Indonesia website and the company's official website to strengthen the explanation about PT Krakatau Stell, Tbk. 2009 - 2018 period. 


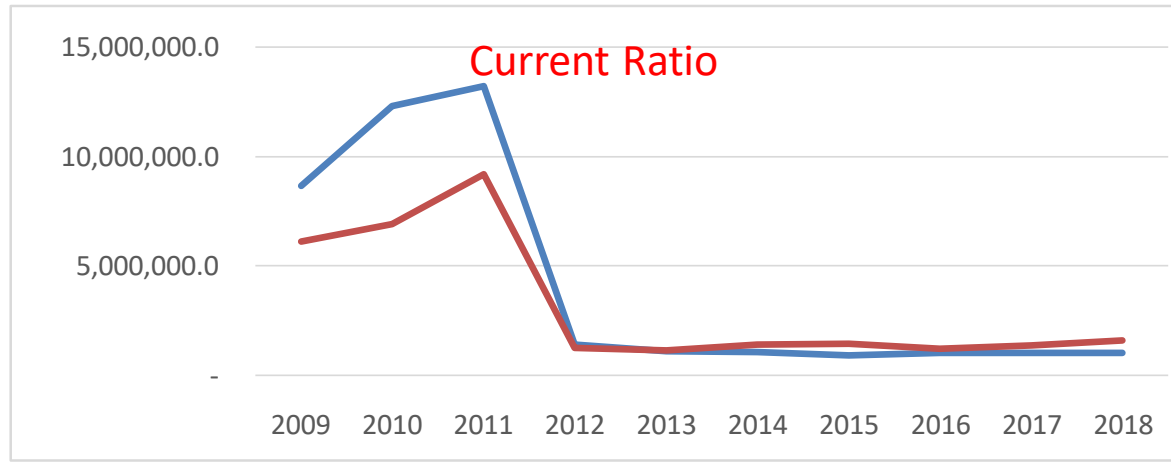

Figure 1. Current Ratio

Current assets that occurred in KS, Tbk in 2009 experienced an increase then in 2009 to 2011 experienced an increase in 2012 and decreased until 2015, then in 2016 it experienced an increase until 2018.

PT KS, Tbk's current debt experienced an increase in 2007 to 2008, then there was a decrease from 2008 to 2009, current debt in 2010 increased but was not significant, then in 2011 it experienced an increase, when viewed from 2012 to 2019 debt smoothly does not experience significant or significant increase and decrease.

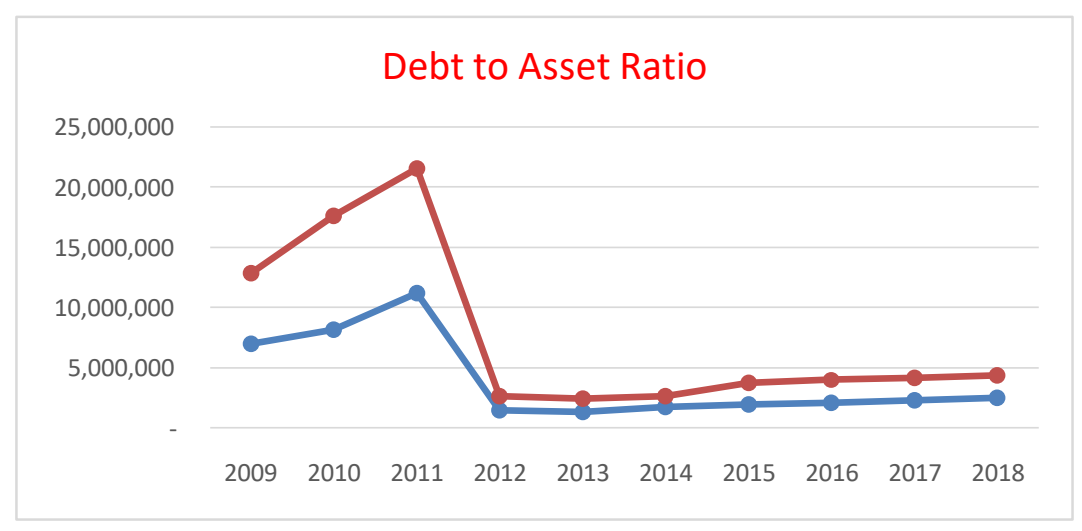

Figure 2. Debt to Asset Ratio

From the chart above, there can be tianalis that the largest total debt occurred in 2011 to 2017 experiencing a decrease in the Debt to Asest Ratio (DAR) that occurred at PT KS, Tbk.

From the results of the pre-survey the author will take data from the IDX Indonesia website and the company's official website. The data that the author takes is the financial report of PT KS Tbk is in the following graphical form: 


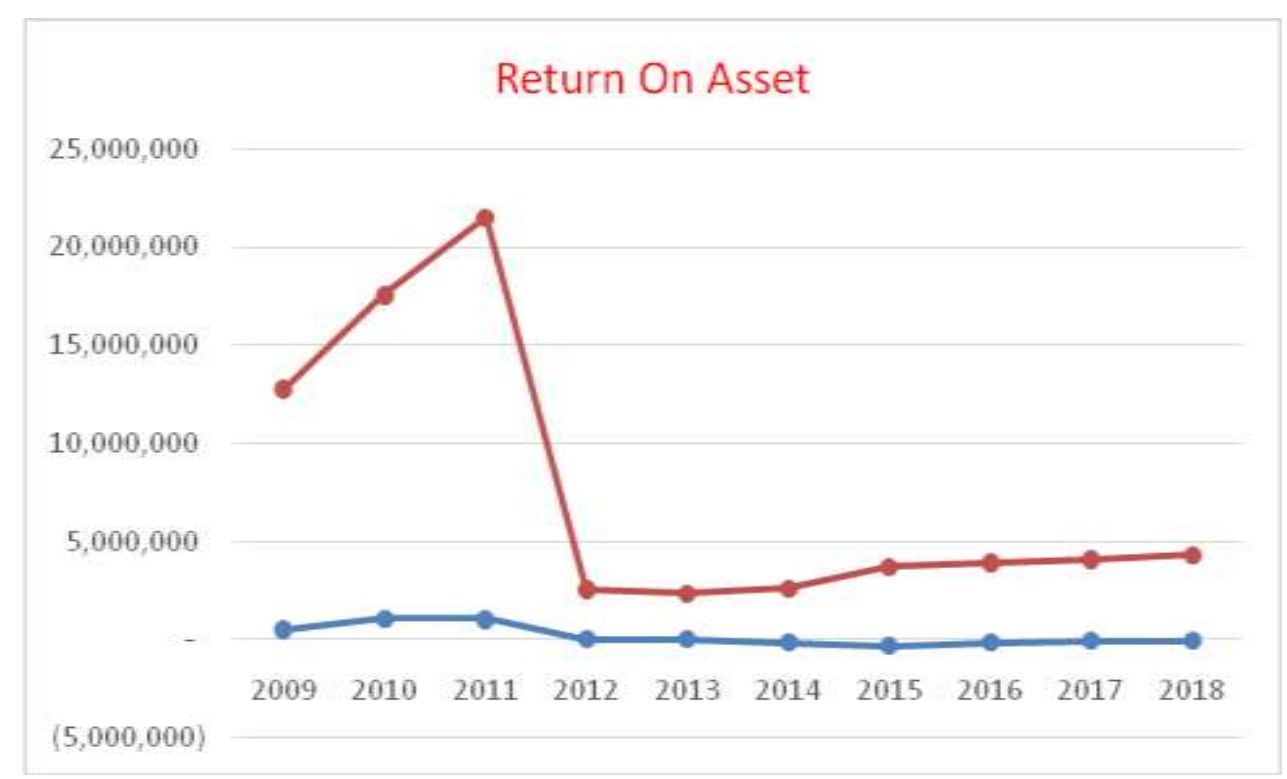

Figure 3. Return On Asset Ratio

Analysis of the graph above regarding Return On Assets (ROA) for this industrial company gets a profit before interest and tax of 792,733. In 2008 the company pocketed a profit before interest and tax of 1,360,388, then in 2009 it decreased, but in 2010 it increased, then in subsequent years it decreased, from 2011 to 2015, but the peak occurred in 2015. it can be seen from the data presented that the company suffered a loss, but in 2016 the company was able to rise from its downturn and managed to rise as seen from the value of ROA which began to increase, then in 2019 it increased, and had a significant effect on company value.

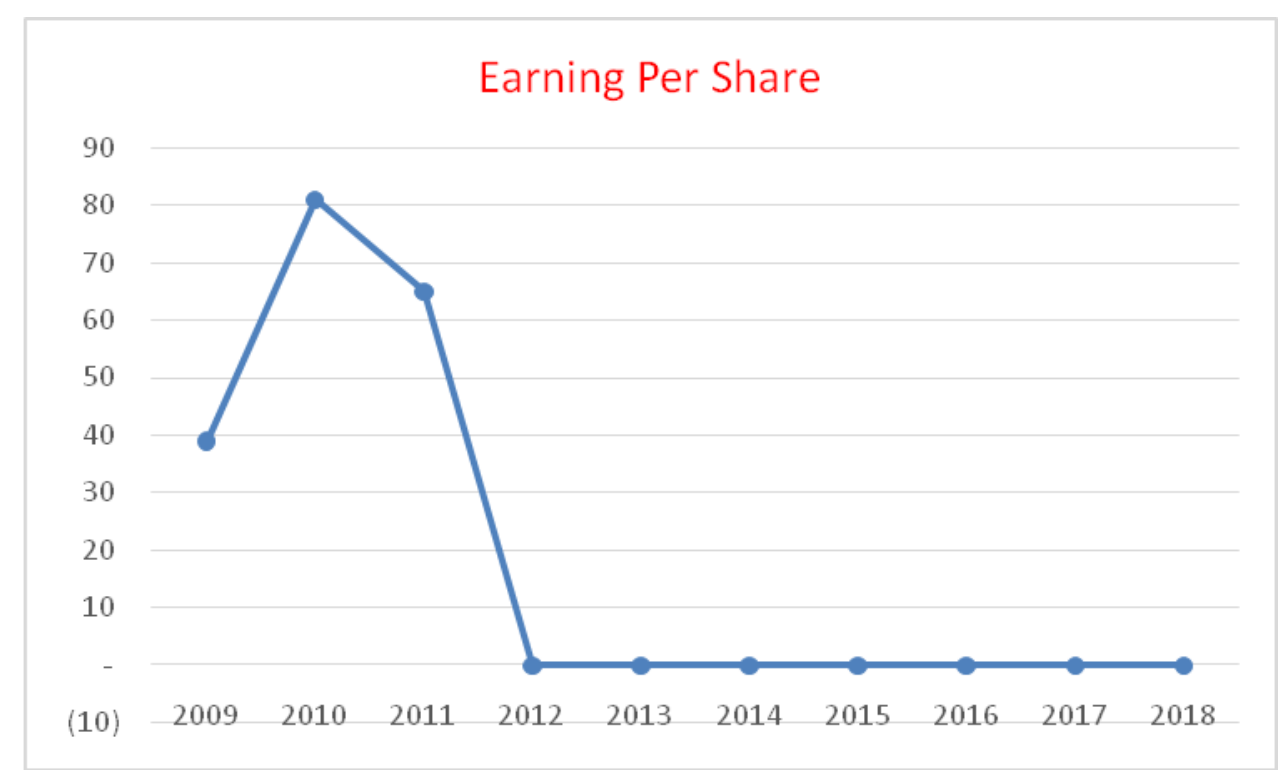

Figure 4. Earning Per Share

Analysis of the graph above regarding Earning Per Share from 2009 amounting to Rp. 39, - increased to Rp. 81 per share for 2010, and decreased to Rp. 65 , - per share for the year 2011. For the years 2012 to 2018, there are losses, it can be seen from the table above. 


\section{Review of Literatures}

\subsection{Definition of Financial Statement Analysis}

According to Harahap (2015: 190), financial statement analysis means outlines Financial statement posts become smaller units of information and see a relationship that is significant or has meaning between one another, both quantitative data and non-quantitative data with the aim of knowing deeper financial conditions which are very important in the process of making decisions.

According to Hery (2015: 132), financial statement analysis is a process of dissecting financial statements into their elements and examining each of these elements with the aim of obtaining a good and precise understanding and understanding of the financial statements themselves.

According to Kasmir (2016: 66), the results of financial statement analysis will also provide information about the company's weaknesses and strengths.

From the four opinions of the experts above regarding financial statement analysis, it can be concluded that financial statement analysis is an analytical tool for company management to see its weaknesses and strengths, aiming to find out deeper financial conditions which are very important in the process of making decisions.

Remund in Lubis et al (2019) states that financial literacy is a measurement of one understands of financial concepts, and the ability and confidence to manage personal finances through appropriate short-term decision making, long-term financial planning, and attention to economic events and conditions.

Financial intermediaries are in a better position to discover and benefit from investment opportunities, perform the role of savings mobilization, ease innovation and manage risk. Therefore, the relationship between economic growth and financial intermediaries' development remains an important subject in economic discourse. (Mansaray, 2020)

\subsection{Forms of Financial Ratios}

Cashmere (2016: 110), the following are forms of financial ratios:

a. Liquidity ratio (Liquidty Ratio), this ratio shows the company's ability to pay its shortterm debts that are due.

b. The leverage ratio (Leverage Ratio), or solvency ratio, is a ratio used to measure the extent to which the company's assets are financed with debt.

c. Activity ratio is the ratio used to measure the efficiency level of the company's resource utilization (sales, inventory, accounts receivable collection, and others).

d. Profitability ratio is a ratio to assess the company's ability to seek profit or profit in a certain period.

e. Growth ratio is a ratio that describes a company's ability to maintain its economic position amidst economic growth and its business sector.

f. Valuation ratio, which is a ratio that provides a measure of the management's ability to create the market value of its business above investment costs, such as the ratio of stock prices to income and the ratio of stock market value to the company's book value.

\subsection{The value of the company}

The pace of global economic growth will coincide with the direction of financial market developments, therefore the improving global economic conditions have prompted a shifting of investment from government bonds (safe haven assets) to stocks, which have strong correlation with economic growth. This shifting also shows the increasing risk appetite 
of global investors, reflected in the willingness to invest in riskier assets, such as stocks and government bonds in developing countries. (Baihaqqy et al, 2020)

Company value is very important because high company value will be followed by high prosperity for shareholders. The higher the stock price, the higher the company value. A high company value is the desire of company owners, because a high value shows that the shareholder's prosperity is also high.

\section{Research Methods}

The research object chosen by the author is a company listed on the Indonesia Stock Exchange (BEI), namely PT KS, Tbk, which has an office at Krakatau Steel Building, 4th Floor, Jalan Gatot Subroto, Kav 54, RT.1, RW.4, Kuningan Tim, Setia Budi, City of South Jakarta, Special Capital Region of Jakarta, 12950. Whereas forTo get the data and information needed in this thesis, the author uses the data published on the company's official website and through the Indonesia Stock Exchange (IDX) website, which is located at the Jakarta Stock Exchange Building, Tower II, 1st Floor, Jl. Jendral Sudirman Kav. 52-53, Senayan, Kebayoran Baru, South Jakarta 12190 which can be accessed at www. idx.co.idResearch conducted by the author is descriptive quantitative, meaning research that describes or tells and describes how the results of calculating the company's financial data in the form of financial statements. The data used by the authors in this study are data contained in the financial statements of PT KS, Tbk for the period 2009 to 2018. The population used in this study is the financial statements of PT KS, Tbk for the period 2009 to 2018. The sample used in this study is Current Ratio, Debt to Asset Ratio, and return on assets in the financial statements of PT KS, Tbk for eleven years, from 2009-2018..

\section{Result and Discussion}

\subsection{Analysis of Research Variables}

\section{a. Current Ratio}

According to Kasmir (2016: 146), Current Ratio, is a ratio to measure a company's ability to pay short-term obligations or debts that are due immediately when they are collected. In other words, how many current assets are available to cover short-term liabilities that are due. To calculate the Current Ratio (CR), the following formula is used:

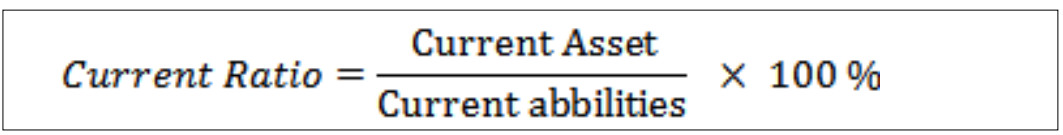

Source: V. Wiratna Sujarweni, (2015: 110)

Table 1. Current Ratio PT Krakatau Steel Tbk for the period 2009-2018 (In percentage)

\begin{tabular}{|c|c|c|}
\hline & Year & CR (X1) \\
\hline 1 & 2009 & 140.79 \\
\hline 2 & 2010 & 177.28 \\
\hline 3 & 2011 & 143.55 \\
\hline 4 & 2012 & 112.47 \\
\hline 5 & 2013 & 96.23 \\
\hline
\end{tabular}




\begin{tabular}{|c|c|c|}
6 & 2014 & 74.90 \\
\hline 7 & 2015 & 61.25 \\
\hline 8 & 2016 & 81.45 \\
\hline 9 & 2017 & 75.02 \\
\hline 10 & 2018 & 61.91 \\
\hline
\end{tabular}

Source: Data processed by the author

Based on the calculation of the Current Ratio at PT Krakatau Steel, Tbk above, there is a decrease every year. Starting in the following year in 2009 the Current Ratio has increased by $6.28 \%$ to $140.79 \%$. In 2010 , current assets increased which caused the Current Ratio to also increase by $36.50 \%$ to $177.29 \%$. In 2011 the Current Ratio decreased by $33.74 \%$ to $143.55 \%$. This was due to the fact that current debt increased significantly and current assets also increased. In 2013, the Current Ratio decreased by $16.24 \%$ to $96.23 \%$, this was because current assets and current debt decreased.

Furthermore, in 2014 the Current Ratio decreased by $21.32 \%$ to $74,90 \%$ of this is because this year current assets have decreased while current debt has increased. Then in 2015 current assets also decreased and current debt also increased (although not significant) resulting in a decrease in the Current Ratio by $14.01 \%$ to $61.25 \%$. But in 2016 current assets increased and current debt decreased so that causing the Current Ratio to increase by $20.55 \%$ to $81.45 \%$. The last year 2017 Current Ratio decreased by $6.43 \%$ to $75.02 \%$ this was due to the increase in current assets and current debt and in 2018 decreased. Then in 2015 current assets also decreased and current debt also increased (although not significant) resulting in a decrease in the Current Ratio by $14.01 \%$ to $61.25 \%$. But in 2016 current assets increased and current debt decreased so that causing the Current Ratio to increase by $20.55 \%$ to $81.45 \%$. The last year 2017 Current Ratio decreased by $6.43 \%$ to $75.02 \%$ this was due to the increase in current assets and current debt and in 2018 decreased.

Then in 2015 current assets also decreased and current debt also increased (although not significant) resulting in a decrease in the Current Ratio by $14.01 \%$ to $61.25 \%$. But in 2016 current assets increased and current debt decreased so that causing the Current Ratio to increase by $20.55 \%$ to $81.45 \%$. The last year 2017 Current Ratio decreased by $6.43 \%$ to $75.02 \%$ this was due to the increase in current assets and current debt and in 2018 decreased. But in 2016 current assets experienced an increase and current debt decreased, causing the Current Ratio to increase by $20.55 \%$ to become $81.45 \%$. The last year 2017 Current Ratio decreased by $6.43 \%$ to $75.02 \%$ this was due to the increase in current assets and current debt and in 2018 decreased. However, in 2016 current assets experienced an increase and current debt decreased, causing the Current Ratio to increase by $20.55 \%$ to become $81.45 \%$. The last year 2017 Current Ratio decreased by $6.43 \%$ to $75.02 \%$ this was due to the increase in current assets and current debt and in 2018 decreased.

\section{b. Debt to Asset Ratio}

According to Kasmir (2016: 156), Debt to Asset is a debt ratio used to measure the ratio between total debt and total assets. In other words, how much the Company's assets are financed by debt or how much the amount of the Company's debt affects the management of akiva. To calculate the Debt to Asset Ratio, the following formula is used:

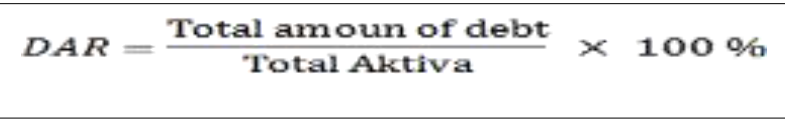


Table 2. Debt to Asset Ratio PT Krakatau Steel Tbk for the period 2009-2018 (In percentage)

\begin{tabular}{|c|c|c|}
\hline No. & Year & DAR $(\mathbf{X 2})$ \\
\hline 1 & 2009 & 54.31 \\
\hline 2 & 2010 & 46.40 \\
\hline 3 & 2011 & 51.86 \\
\hline 4 & 2012 & 56.44 \\
\hline 5 & 2013 & 55.79 \\
\hline 6 & 2014 & 65.68 \\
\hline 7 & 2015 & 51.70 \\
\hline 8 & 2016 & 53.27 \\
\hline 9 & 2017 & 54.97 \\
\hline 10 & 2018 & 58.12 \\
\hline
\end{tabular}

Source: Data processed by the author

Based on the calculation of the Debt to Asset Ratio at PT Krakatau Steel, Tbk for the 2009-2018 period, it can be seen that the Debt to Asset Ratio has fluctuated every year starting from 2009 , which decreased by $10.07 \%$ to $54.31 \%$ this happened because of total debt and total assets have decreased. In 2010, the Debt to Asset Ratio decreased by $7.91 \%$ to 46.40\%. In 2011, the Debt to Asset Ratio increased by $4.58 \%$ to $51.86 \%$. This was due to an increase in total debt and total assets.

Furthermore, in 2012 the Debt to Asset Ratio continued to increase by $4.58 \%$ to $56.44 \%$ this was due to total assets and total debt which began to shrink, in 2013 the Debt to Asset Ratio decreased by $0.65 \%$ to 55, 79\%. Then in 2014 the total debt and total assets experienced an increase, this resulted in the value of the Debt to Asset Ratio which also increased by $9.89 \%$ to $65.68 \%$. The following year 2015 Debt to Asset Ratio decreased by $13.97 \%$ to $51.70 \%$. In 2016, the Debt to Asset Ratio increased from $51.70 \%$ to $53.27 \%$, this was due to an increase in total assets and total debt. In 2017, total debt increased but was accompanied by an increase in total assets so that the Debt to Asset Ratio rose again this year to 54.97 .

\section{c. Return on Assets}

According to V. Wiratna Sujarweni (2015: 114), Return on Assets is a ratio used to measure the ability of capital invested in all assets to generate net profits. To calculate the Return on Assets, the following formula is used:

$$
\text { ROA }=\frac{\text { Net Profit }}{\text { Total Assets }} \times 100 \%
$$


Table 3. Return on Assets PT Krakatau Steel Tbk for the period 2007-2017 (In million rupiah)

\begin{tabular}{|c|c|c|}
\hline No. & Year & ROA (Y) \\
\hline 1 & 2009 & 3.87 \\
\hline 2 & 2010 & 6.03 \\
\hline 3 & 2011 & 4.75 \\
\hline 4 & 2012 & $(0.76)$ \\
\hline 5 & 2013 & $(0.57)$ \\
\hline 6 & 2014 & $(5.93)$ \\
\hline 7 & 2015 & $(8.82)$ \\
\hline 8 & 2016 & $(4.59)$ \\
\hline 9 & 2017 & $(2.09)$ \\
\hline 10 & 2018 & $(1.80)$ \\
\hline
\end{tabular}

Source: Data processed by the author

Based on the results of the calculation of Return on Assets of PT Krakatau Steel, Tbk, it is explained that the Return on Assets has experienced instability every year starting in 2009, it decreased by $3.87 \%$, up to $6.03 \%$, this happened because of net income, and decreased in 2010 Return on Assets experienced a decrease of $4.75 \%$.

In 2012 to 2018 there was an increase and decrease in losses as a result of which the company lost more and more.

Table 4. Earnong per Share PT Krakatau Steel Tbk for the period 2009-2018 (In million rupiah)

\begin{tabular}{|c|l|l|}
\hline No. & Year & EPS (Z) \\
\hline 1 & 2009 & 39 \\
\hline 2 & 2010 & 81 \\
\hline 3 & 2011 & 65 \\
\hline 4 & 2012 & $(0.0012)$ \\
\hline 5 & 2013 & $(0.0002)$ \\
\hline 6 & 2014 & $(0.0086)$ \\
\hline 7 & 2015 & $(0.0203)$ \\
\hline 8 & 2016 & $(0.0066)$ \\
\hline 9 & 2017 & $(0.0042)$ \\
\hline 10 & 2018 & $(0.0110)$ \\
\hline
\end{tabular}

Based on the results of the calculation of Earning Per Share of PT Krakatau Steel, Tbk, it is explained that Earning Per Share has experienced instability every year starting in 2009. Earnings per share amounted to Rp. 39, - and increased in 2010 by Rp. 42, - to become EPS of Rp. 81, - decreased in 2011 to Rp. 65, - per share.

In 2012 the company suffered infinite losses resulting in the company's financial condition experiencing cash flow difficulties, from 2012 to 2018 it suffered enormous losses.

\subsection{Descriptive Statistical Analysis}

Descriptive statistics show the amount of data $(\mathrm{N})$ used in this study and can show the maximum value, minimum value, average value (mean) and standard deviation of each of the 
variables studied, including Current Ratio, Debt to Asset Ratio, and Return on Assets. The results of the descriptive statistical data processing which became the research variables using SPSS version 2.0 are presented in table 4.4, below:

Table 4. Descriptive Analysis Results

\begin{tabular}{|l|c|c|c|c|}
\hline \multicolumn{1}{|c|}{ CR_X1 } & DAR_X2 & ROA_Y & EPS_Z \\
\hline \multicolumn{1}{|c|}{ Mean } & 102.4856 & 54,85260 & -0.991306 & 18.49479 \\
\hline Median & 88.83782 & 54,63726 & -1.279336 & -0.002700 \\
\hline Maximum & 177.2794 & 65.67657 & 6,033118 & 81.00000 \\
\hline Minimum & 61,25089 & 46,39722 & -8.819592 & -0.020300 \\
\hline Std. Dev. & 39,70913 & 4.993312 & 4.792430 & 31.42262 \\
\hline Skewness & 0.667197 & 0.603103 & 0.002183 & 1.166697 \\
\hline Kurtosis & 2.147451 & 3.801661 & 2.013571 & 2.651488 \\
\hline & & & & \\
\hline Jarque-Bera & 1.044769 & 0.873997 & 0.405442 & 2.319245 \\
\hline Probability & 0.593105 & 0.645972 & 0.816506 & 0.313605 \\
\hline & & & & \\
\hline Sum & 1024,856 & 548.5260 & -9.913059 & 184,9479 \\
\hline Sum Sq. Dev. & 14191.33 & 224.3985 & 206,7065 & 8886,428 \\
\hline & & & & 10 \\
\hline Observations & 10 & 10 & & 10 \\
\hline
\end{tabular}

Source: Data Processed Results

Based on the results of the calculation of the table above, it can be seen that the amount of data $(\mathrm{N})$ used is 10 data. The value of the CR variable average (mean) of102.4856, the minimum value is 61,25089, and the maximum value 177.2794, with a standard foreign exchange value of 39,70913. While the DAR variable has 10 minimum values of data46,39722, the maximum value 65.67657, and the mean (mean) is 54,85260, with a standard deviation of4.993312. For the ROA variable, the minimum value is negative8.819592 , while the greatest value is 6,033118 , with the average -0.991306 , the standard deviation 4.792430 and For the EPS variable the minimum value is negative -0.020300 , while the greatest value is 81.00000 , with the average 18.49479 , the standard deviation 31.42262 .

\section{a. Hypothesis test}

The data analysis technique used to answer the hypothesis of the magnitude of the effect of CR on ROA, DAR on ROA, CR and DAR simultaneously on ROA and ROA on EPS in this study will be carried out regression test, determination coefficient test, t-test and f-test. 


\section{Hypothesis Testingis Effect of CR on ROA}

Table 5. Effect of CR on ROA

Dependent Variable: ROA_Y

Method: Least Squares

Date: 11/5/20 Time: 23:41

Sample: 110

Included observations: 10

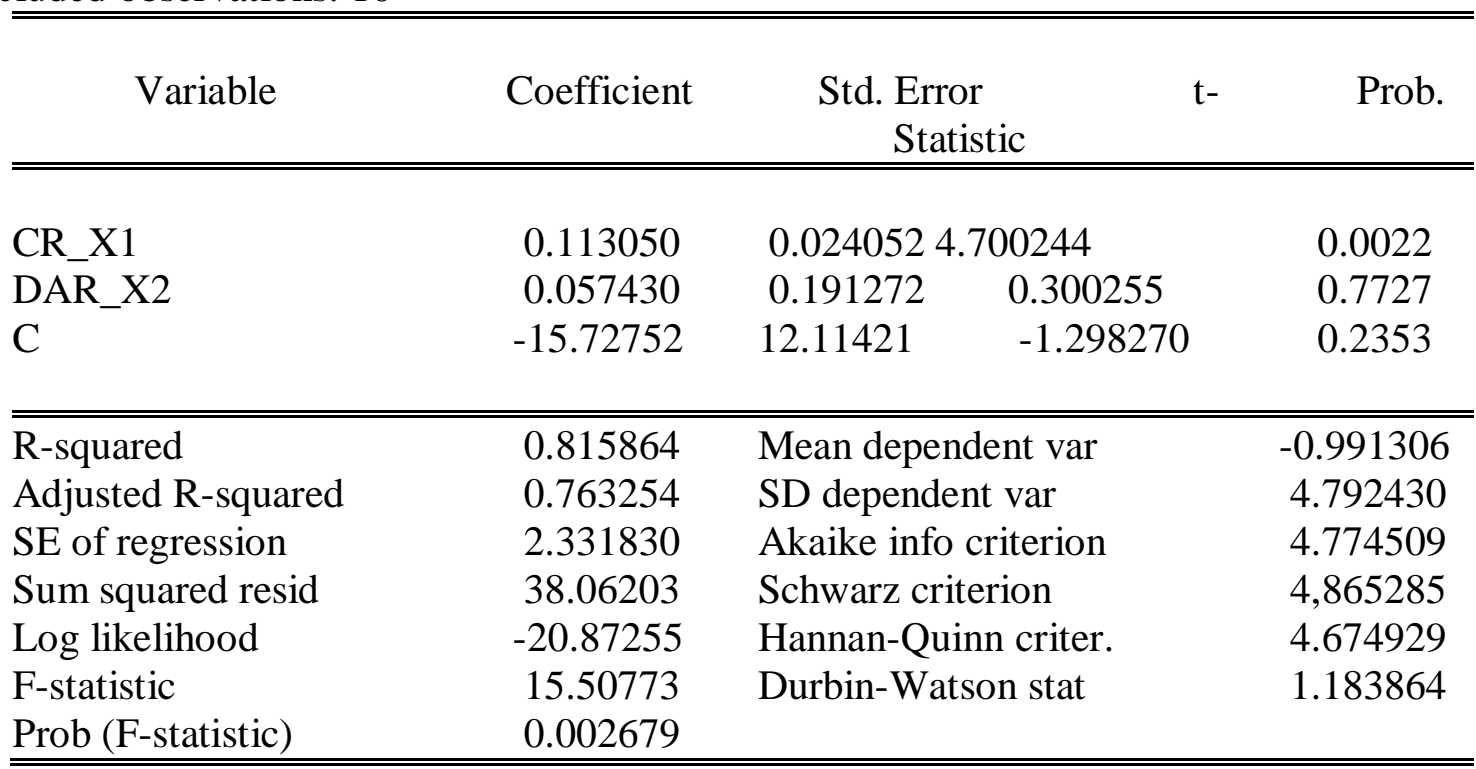

The results of panel data regression analysis in table 4.5 show the results of the $\mathrm{t}$-count variable Current Ratio amounted to 4,700 , a positive sign means that it has a positive relationship. While the t-table with $\alpha=5 \%$ and $\mathrm{df}=\mathrm{nk}$, $\mathrm{df}=9$, then the t-table $(0.05 ; 9)=$ 2.262 (2-way test). So that $\mathrm{t}$-count is greater than t-table $(4,700>2,262)$ so $\mathrm{H} 0$ is rejected and $\mathrm{H} 1$ is accepted and it can be concluded that the independent variable has an effect on the dependent variable. Then the probability valueCurrent Ratio smaller than the constant $(0.0022<0.05)$, the result is significant, meaning that there is a positive influence from the independent variable individually on the dependent variable ROA.

a) Regression Equations

Based on the results of the Eviews above, the regression model equation between the return on equity and debt to equity ratio variables is obtained as follows:

$\mathrm{Y}=-15,728-0.113 \mathrm{X}+€$ it

From the above equation it can be explained that:

- A constant of 15,728 indicates that if there are or are not independent variables (the current ratio in the i-th observation and the ket period is zero, then the return on assets value increases by 15,728 .

- The regression coefficient of 0.113 indicates that if the curret ratio value in the $i$-th observation and t-period increases by 1 , the return on assets value in the $\mathrm{i}$-th observation and t-period increases by 0.113 .

b) The coefficient of determination and correlation coefficient

This coefficient shows the percentage of the current ratio variable used in the model that is able to explain the return on assets variable. Based on table 4.5 , the amount of the 
Adjusted R-Squared (R2) number is 0.816 . This shows that the percentage of the contribution of the influence of the independent variable on the dependent variable is $81.6 \%$ or it can be interpreted that the independent variable used in the model is able to explain $81.6 \%$ of the dependent variable. While the remaining $18.4 \%$ is influenced by other factors outside the regression model. From the coefficient of determination (R2) 0.816, it is known that the correlation coefficient $(\mathrm{R})$ is 0.184 which indicates a strong relationship, because it is in the coefficient interval of $0.600-0.799$.

\section{Hypothesis Testingis Effect of CR on ROA}

The effect of DAR on ROA can be seen from the table of data management results using the EViews software below

Table 6. Effect of DAR on ROA

Dependent Variable: ROA_Y

Method: Least Squares

Date: 11/5/20 Time: $23: 41$

Sample: 110

Included observations: 10

\begin{tabular}{lcccr}
\hline \hline \multicolumn{1}{c}{ Variable } & Coefficient & \multicolumn{2}{c}{ Std. Error } & Statistic \\
& & & Prob. \\
& & & \\
CR_X1 & 0.113050 & 0.024052 & 4.700244 & 0.0022 \\
DAR_X2 & 0.057430 & 0.191272 & 0.300255 & 0.7727 \\
C & -15.72752 & 12.11421 & -1.298270 & 0.2353 \\
& & & & \\
\hline \hline & & & \\
R-squared & 0.815864 & Mean dependent var & 0.991306 \\
Adjusted R-squared & 0.763254 & SD dependent var & 4.792430 \\
SE of regression & 2.331830 & Akaike info criterion & 4.774509 \\
Sum squared resid & 38.06203 & Schwarz criterion & 4,865285 \\
Log likelihood & -20.87255 & Hannan-Quinn criter. & 4.674929 \\
F-statistic & 15.50773 & Durbin-Watson stat & 1.183864 \\
Prob (F-statistic) & 0.002679 & & \\
\hline \hline
\end{tabular}

The results of the panel data regression analysis in table 4.6 show the results of the tcount variabledebt to asset ratio amounted to 0.300 , a positive sign means that it has a positive relationship. While the t-table with $\alpha=5 \%$ and $\mathrm{df}=\mathrm{nk}, \mathrm{df}=9$, then the t-table $(0.05$; $9)=2.262$ (2-way test). So that $\mathrm{t}$-count is greater than $\mathrm{t}$-table $(0.300<2.262)$, so H0 is not rejected and it can be concluded that the independent variable has no effect on the dependent variable. Then the probability valueebt to asset Ratio smaller than the constant $(0.778>0.05)$, the result is significant, meaning that the influence of the independent variables individually does not affect the ROA variable.

a) Regression Equations

Based on the results of Eviews table 4.7, the regression model equation between the cureent ratio, debt to assets ratio and return on assets variable is obtained as follows:

$\mathrm{Y}=-15,728-0.113 \mathrm{X} 1-0.057 \mathrm{X} 2+€$ it

From the above equation it can be explained that: 
- A constant of $-15,728$ indicates that if the independent variables (curret ratio and debt to assets ratio) in the $\mathrm{i}$-th observation and t-period are zero, then the return on equity value is 15,728

- The regression coefficient of 0.113 shows that if the value of the debt to asset ratio in the $\mathrm{i}$-th observation and t-period increases by 1 , the return on equity value in the $\mathrm{i}$-th observation and t-period increases by 0.113 .

- The regression coefficient of 0.057 indicates that if the value of return on assets in the $i$-th observation and t-period increases by 1 , the return on equity in the $\mathrm{i}$-th observation and $\mathrm{t}$ period increases by 0.057 .

b) The coefficient of determination and correlation coefficient

Based on table 4.7, the amount of Adjusted R-Squared (R2) is 0.816.This shows that the percentage of the contribution of the influence of the independent variable on the dependent variable is $81.6 \%$ or it can be interpreted that the independent variable used in the model is able to explain $81.6 \%$ of the dependent variable. While the remaining $18.4 \%$ is influenced by other factors outside the regression model. From the coefficient of determination (R2) 0.816, it is known that the correlation coefficient (R) is 0.184 which indicates a strong relationship, because it is in the coefficient interval.

\section{Hypothesis Testing the Effect of ROA on EPS}

To determine the effect of ROA on EPS, it can be determined by using several tests, including:

\section{Table 8. Effect of ROA on EPS}

Dependent Variable: EPS_Z

Method: Least Squares

Date: 11/5/20 Time: 23:43

Sample: 110

Included observations: 10

\begin{tabular}{lrrrr}
\hline \multicolumn{1}{c}{ Variable } & Coefficient & Std. Error & t-Statistic & \multicolumn{1}{c}{ Prob. } \\
& & & \\
\multicolumn{1}{c}{ ROA_Y } & 5.477078 & 1.274371 & 4.297867 & 0.0026 \\
C & 23,92425 & 5.930050 & 4.034409 & 0.0038 \\
\hline \hline R-squared & 0.697790 & Mean dependent var & 18.49479 \\
& & \\
Adjusted R-squared & 0.660014 SD dependent var & 31.42262 \\
SE of regression & 18.32201 Akaike info criterion & 8.830939 \\
Sum squared resid & 2685,567 Schwarz criterion & 8.891456 \\
Log likelihood & -42.15470 Hannan-Quinn criter. & 8.764552 \\
F-statistic & 18.47166 Durbin-Watson stat & 1.503036 \\
Prob (F-statistic) & 0.002623 & & \\
& & & \\
\hline
\end{tabular}

The results of panel data regression analysis showed that the t-count of the return on assets variable was 4,298, a positive sign means that it is in a positive area. While t-table with $\alpha=5 \%$ and $\mathrm{df}=\mathrm{n}-\mathrm{k}, \mathrm{df}=9$, then $\mathrm{t}$-table $(0.05 ; 9)=2.262$ (2-way test). So that the $\mathrm{t}$-count is smaller than the t-table (4.298> 2.262) so HO is rejected and it can be concluded that the independent variable has a significant effect on the dependent variable. Then the probability 
value of return on assets is smaller than the constant $(0.0026<0.05)$, then the result is significant, meaning that there is an influence from the independent variables individually on the dependent variable.

a) Regression Equations

Based on the results of the Eviews above, the regression model equation is obtained between the dividend payout ratio and return on equity as follows:

$\mathrm{Y}=23.924+5.477 \mathrm{X}+€_{\text {it }}$

From the above equation it can be explained that:

- A constant of 23,924 indicates that if there is or no independent variable (return on equity) in the $\mathrm{i}$-th observation and t-period is zero, then the dividend payout ratio value is reduced by 23,924 .

- The regression coefficient of 5,477 shows that if the value of return on equity in the i-th observation and t-period increases by 1 , the dividend payout ratio value in the $\mathrm{i}$-th observation and t-period increases by 5,477 .

b) The coefficient of determination and correlation coefficient

This coefficient shows how much the percentage of the independent variable return on assets used in the model is able to explain the dependent variable earnings per share ratio (EPS). Based on table 4.8, the amount of Adjusted R-Squared (R2) is 0.698. This shows that the percentage of the contribution of the influence of the independent variable on the dependent variable is $69.80 \%$ or it can be interpreted that the independent variable used in the model is able to explain $69.80 \%$ of the dependent variable. While the remaining $30.20 \%$ is influenced by other factors outside the regression model.

\subsection{Discussion of Research Results}

This study will discuss the results of statistical tests regarding the analysis of the influence of the variable curren ratio and debt to assets ratio on return on assets and its impact on firm value (EPS) at PT. Krakatau Still which has gone public.

\section{a. Effect of CR on ROA}

The results of testing the hypothesis of the effect of the current ratio on return on assets can be seen from the acquisition of the $\mathrm{CR}$ variable t-count of 0.113 and has a significant value smaller than $\alpha=0.05$, namely $(0.022<0.05)$, so that $\mathrm{H} 0$ is rejected and $\mathrm{H} 1$ accepted, which means that the independent variable CR partially has a positive effect on ROA

The results of this study are in line with previous research, namely research by Mahardhika, PA, (2016) which states that the Current Ratio (CR) has a positive effect on ROA, the same result is also conveyed by Melianti Saragih (2015) whose research results state that the Current Ratio has a positive and significant effect against Return on Assets.

\section{b. Effect of DAR on ROA}

The results of hypothesis testing on the effect of debt to assets ratio on debt of asset ratio can be seen from the t-count of the DAR variable of 0.0574 and has a significant value smaller than $\alpha=0.05$, namely $(0.7727>0.05)$, so that $\mathrm{H} 0$ is not rejected., which means the independent variable X2 (DAR) partially has no significant effect on variable Y (ROA).

The greater the Debt to Asset Ratio, the greater the level of dependence of the company on external parties (creditors) and the greater the burden of debt costs (interest costs) that must be paid by the company. The results of this study are in line with Robi Pramana Kusuma (2016) who stated that DAR has no effect on company profitability (Return on Assets). 


\section{c. Simultaneous Effect of CR and DAR on ROA}

Simultaneously the independent variable f-count is 15.51 and has a significant value smaller than $\alpha=0.05$, namely $(0.027<0.05)$. So that $\mathrm{H} 0$ is rejected, H1 is accepted, which means that the independent variables together have a significant effect on the dependent variable Y (ROA)

Based on the results of testing the variable Current Ratio and Debt to Asset simultaneously (Test F) on Return on Assets shows that there is an insignificant influence. This is indicated by the value of Fcount greater than Ftable $(8.421>4.46)$ with a significant value of 0.011 greater than 0.05 . The correlation coefficient value is 0.892 . This indicates that the correlation or relationship between Return on Assets with Current Ratio and Debt to Asset has a very strong level of relationship, namely 0.823 where the coefficient interval is between $(0.80-1,000)$. For the Multiple Linear Regression test, the regression equation $\mathrm{Y}=-$ $21.227+0.089 \mathrm{X} 1+0.227 \mathrm{X} 2$ explains that if the Current Ratio and Debt to Asset are 0 (zero), then the Return on Assets value is negative 21.227,

Nilai R Square sebesar 0,678 atau 67,8\% artinya Return on Assets dipengaruhi oleh Current Ratio dan Debt to Asset sebesar 67,8\%. Sedangkan sisanya sebesar 32,2\% dipengaruhi oleh faktor-faktor lain diluar model.

\section{d. Effect of ROA on EPS}

Partially, from the t-count of the ROA variable, it is 5,477 and has the effect of a significant value that is smaller than $\alpha=0.05$, namely $(0.0026<0.05)$. The positive number $(+)$ on the t-count shows a unidirectional movement between the ROA and EPS variables, where when ROA increases, EPS will increase, and vice versa if ROA decreases, EPS will decrease.

\section{Conclussion}

This study aims to identify and analyze this phenomenon, so the authors are interested in conducting research with the title of the effect of curent ratio (X1) and debt to assets ratio (X2) on return on assets (Y) and its impact on earnings per share) EPS ) at PT. Krakatau Steel, Tbk, 2009-2018 period. Based on the results of the tests that have been carried out, the following conclusions are obtained:

1. The effect of the DER ratio on ROA

Based on the research results, the authors conclude that the curent ratio has a significant effect on return on assets.

2. The effect of the DAR ratio on ROA

Based on the research results, the authors conclude that the debt on asset ratio does not have a significant effect on ROA.

3. Simultaneous effect of CR and DAR on ROA

Based on the research results, the authors conclude that the curent ratio and debt to assets ratio simultaneously have a significant effect on ROA. The R Square value of 0.678 or $67.8 \%$ means that the Return on Assets is influenced by the Current Ratio and Debt to Asset of $67.8 \%$. While the remaining $32.2 \%$ is influenced by other factors outside the model.

4. The effect of ROA on EPS

Based on the results of the study, the authors conclude that return on assets has a significant effect of $69.8 \%$ on earnings per share while the remaining $30.20 \%$ 


\section{References}

Abdullah, M. (2014). Manajemen dan Evaluasi Kinerja Karyawan. Aswaja Pressindo: Yogyakarta

Amelia, R. W., \& Sunarsi, D. (2020). Pengaruh Return On Asset Dan Return On Equity Terhadap Debt To Equity Ratio PadA PT. Kalbe Farma, TBK. Ad Deenar: Jurnal Ekonomi dan Bisnis Islam, 4(01), 105-114.

Appley A, Lawrence dan Lee, Oey Liang. (2010). Pengantar Manajemen. Salemba Empat: Jakarta

Cahyono, Y., Jihadi, . M., Arifin, .Z., Purnamasari, . W., Musnaini, ., Wijoyo, . H., Fitriaty, ., Putra, . R. S., Putri, . R. A., Muliansyah, . D., Suryani, . P. \& Purwanto, . A. (2020) Do Servant Leadership Influence Market Performance? Evidence from Indonesian Pharmacy Industries. Systematic Reviews in Pharmacy, 11 (9), 439451.doi: $10.31838 /$ srp.2020.9.62

Baihaqqy, M. et al. (2020). The Effect of Financial Literacy on the Investment Decision. Budapest International Research and Critics Institute-Journal (BIRCI-Journal). P. 30733083.

Brigham, Eugene F and Joel F. Houston. (2010). Dasar-Dasar Manajemen Keuangan. Alih bahasa Ali Akbar Yulianto. Buku satu. Edisi sepuluh. PT Salemba Empat: Jakarta.

Fahmi, Irham . (2016). Pengantar Manajemen Keuangan (tori dan Soal Jawab). ALFABETA: Bandung

Ghozali, Imam. (2016). Aplikasi Analisis Multivariete dengan Program IBM SPSS. Cetakan ke-8. Badan penerbit Universitas Dipenogoro: Semarang

Gumilar, I., Sunarsi, D. (2020). Comparison of financial performance in banking with high car and low car (Study of banks approved in the kompas 100 index for the period 20132017). International Journal of Psychosocial Rehabilitation. Volume 24 - Issue 7

Handoko, T. Hani. (2011). Manajemen. Cetakan kedelapan belas. BPFE: Yogyakarta.

Harahap, Sofyan Syafri. 2009. Analisis Kritis atas Laporan Keuangan. PT. Raja Garfindo Persada: Jakarta.

Harmono. (2011). Manajemen Keuangan. Edisi satu, Cetakan kedua. Bumi Aksara: Jakarta

Hasibuan . (2012). Dasar-dasar Perbankan. Haji Masagung: Jakarta

Haudi, H. W., \& Cahyono, Y. (2020). Analysis Of Most Influential Factors To Attract Foreign Direct Investment. Journal of Critical Reviews, 7(13), 4128-4135.

Hery. (2015). Analisis Laporan Keuangan. Cetakan Pertama, Penerbit CAPS (Center for Academic Publishing Service)

Hidayat, A., \& Sunarsi, D. (2020). Faktor-Faktor Yang Mempengaruhi Dana Pihak Ketiga Dan Dampaknya Terhadap Profitabilitas (Survey Pada Bpr Syariah Di Jawa Barat Tahun 2014-2017). Jurnal Proaksi, 7(1), 54-65.

Horne, Van dan Wachowichz. (2011). Prinsip-Prinsip Manajemen Keuangan. Edisi bahasa Indonesia. Salemba Empat: Jakarta

Ismail, Solihin. (2009). Pengantar Manajemen. Erlangga: Jakarta

Kasmir. (2010). Pengantar Manajemen Keuangan. Kencana Prenada Media Group: Jakarta

Lubis, A, et al. (2019). Antecedents Effect of Financial Inclusion for the People of North

Sumatera. Budapest International Research and Critics Institute-Journal (BIRCIJournal). P. 401-408.

Martono dan Agus Harjito. (2011). Manajemen Keuangan. Penerbit Ekonisia: Yogyakarta.

Mansaray, H. (2020). Organizational Strategies and Performance in the Banking Industry Focused on the Transnational Banks in Sierra Leone: An Ex Post Facto Study. 
Budapest International Research and Critics Institute-Journal (BIRCI-Journal). P. 31853196.

Priyatno, Dwi. (2013). “Analisis Korelasi, Regresi dan Multivariate dengan SPSS”. Cetakan ke-1. Yogyakarta. Gava Media.

Nofiana, L., \& Sunarsi, D. (2020). The Influence of Inventory Round Ratio and Activities Round Ratio of Profitability (ROI). JASa (Jurnal Akuntansi, Audit dan Sistem Informasi Akuntansi), 4(1), 95-103.

Nuryani,Y. D Sunarsi. (2020). The Effect of Current Ratio and Debt to Equity Ratio on Deviding Growth. JASa (Jurnal Akuntansi, Audit dan Sistem Informasi Akuntansi) 4 (2), 304-312.

Perbowosari, H., Hadion Wijoyo, S. E., SH, S., MH, M., \& Setyaningsih, S. A. (2020). Pengantar Psikologi Pendidikan. Penerbit Qiara Media.

Puspitasari, Evita. (2011). Analisis Laporan Keuangan. Edisi Keempat. Cetakan Kedua. Universitas Terbuka: Jakarta

Riyanto, Bambang, (2010). Dasar-dasar Pembelajaran Pembelanjaan Perusahaan. BPFE: Yogyakarta

Safroni, Ladzi.(2012). Manajemen dan Reformasi Pelayanan Pelayanan Publik dalam Konteks Birokrasi Indonesia. Publishing. Surabaya.

Sugiyono. (2015). "Metode Penelitian Kuantitatif, Kualitatif, dan R\&D”. cetakan ke-26. Alfabetal: Bandung

Sujarweni, V. Wiratna. (2015). Manajemen Keuangan Teori, Aplikasi dan Hasil Penelitian. Yogyakarta : PUSTAKA BARU PRESS

Sunarsi, D. (2018). Pengembangan Sumber Daya Manusia Strategik \& Karakterisrik Sistem Pendukungnya : Sebuah Tinjauan. Jurnal Ilmiah MEA (Manajemen, Ekonomi, \& Akuntansi), 2(3), 178 - 194.

Susanti, N., Latifa, I., \& Sunarsi, D. (2020). The Effects of Profitability, Leverage, and Liquidity on Financial Distress on Retail Companies Listed on Indonesian Stock Exchange. Jurnal Ilmiah Ilmu Administrasi Publik, 10(1), 45-52.

Sutrisno. (2012). Manajemen Keuangan Teori, Konsep dan Aplikasi. Ekonisia: Yogyakarta Wijoyo, H. (2018). Analisis Pengakuan Pendapatan dan Beban Kontrak Konstruksi Pada PT. Wahana Tata Riau. Jurnal Ilmu Komputer dan Bisnis, 9(2), 2034-2043.

Wijoyo, H., Handoko, A. L., Santamoko, R., \& Sunarsi, D. (2020). Strategy Model For Character Education Through Digital Media For Courses And Training Participants. EProsiding Pascasarjana Universitas Negeri Gorontalo, 1-8.

Wijoyo, H., Santamoko, R., Muliansyah, D., Yonata, H., \& Handoko, A. L. (2020). The Development Of Affective Learning Model To Improve Student's Emotional Quotient. Journal of Critical Reviews, 7(19), 9292-9297.

Yuangga, K. D., \& Sunarsi, D. (2018). The Influence of Procrastination and Low Time Management on Student Self Efficacy (at MA Soebono Mantofani). PINISI Discretion Review, 2(1), 85-92. 